\title{
Why We Fail to Catch Money Launderers 99.9 percent of the Time
}

by

Kevin Comeau

\begin{abstract}
- Money laundering is an invisible crime whose challenge continues to grow.
- This paper answers two questions: why is it so difficult to detect, investigate and prosecute money-laundering crimes? And, what can be done?

- The key recommendations for answering the latter question include a publicly accessible registry of beneficial ownership, and mandatory declarations of beneficial ownership with meaningful sanctions for false declarations.
\end{abstract}

In 2005, Raymond Baker, a leading authority on financial crimes, used US Treasury Department statistics of illicit money flows and money-laundering conviction rates to show that US law enforcement agencies failed to apprehend money launderers 99.9 percent of the time. ${ }^{1}$ There is no reason to suspect Canada's failure rate is any better, although we do not know for sure. Estimating the extent of money laundering and catching the perpetrators share the same difficulty: the invisibility of the crime.

That leaves us with two questions. Why is it so difficult to detect, investigate and prosecute money-laundering crimes? And what can we do to reduce the problem?

Denis Meunier, in his September 2018 C.D. Howe Institute Commentary, identified a number of areas where Canada has fallen behind other countries in the fight against money laundering (Meunier 2018). Two of his key recommendations are a publicly accessible registry of beneficial ownership, and mandatory declarations of beneficial ownership with meaningful sanctions for false

The author thanks Jeremy Kronick, Paul Bourque, Frank Chong, Blake Goldring, Philip Howell, anonymous reviewers and members of the Financial Services Research Initiative of the C.D. Howe Institute for comments on an earlier draft. He retains responsibility for any errors and the views expressed.

1 The United Nations estimates the global percentage at 99.8 percent (UNODC 2011). 
declarations. Unfortunately, both were excluded from the recommendations of the House of Commons Standing Committee on Finance in its November 2018 report on money laundering (Canada 2018; henceforth referred to as FINA Report). More recently, the federal government amended the Canada Business Corporations Act (CBCA) to require federally incorporated companies to collect and record specified beneficial ownership information concerning persons exercising significant control over the corporation. Unfortunately, not only is that information not accessible by the public, it is not even accessible by law enforcement agencies and competent authorities such as FINTRAC (Canada's financial intelligence agency for money laundering) and the Canada Revenue Agency, as is the international standard recommended by the Financial Action Task Force (FATF) (FATF 2012). Instead, the legislation only provides the right of access to the Director under the CBCA and shareholders and creditors of the corporation.

Working from first principles, this E-Brief explains why the two recommendations are instrumental to combatting money laundering. It identifies three unique advantages money launderers enjoy over those tasked with investigating and prosecuting their crimes, from which it derives the objectives and legislative initiatives needed to reduce those advantages. The aim of this report is to help us understand why Canada has been unable to catch the bad guys, and how the two recommendations significantly increase the chances of doing so.

\section{The Invisible Crime by the Anonymous Criminal}

Money laundering is a derivative crime; it is the process by which a person disguises the origin of illegally obtained proceeds so they appear to have originated from a legitimate source. Money laundering almost always occurs at a different time and place than its underlying predicate crime (for example, drug trafficking, government corruption, tax fraud), and often involves different actors. That separation of time, place and actors creates the appearance of a benign event - merely another legitimate transaction in a world of millions of legitimate transactions. As a result, an overwhelming majority of the time, law enforcement agencies not only do not know who committed the money-laundering crime or where the crime was committed; they do not even know a crime was committed at all.

The effective invisibility of the crime of money laundering and the anonymity of its perpetrators give money launderers a massive advantage over those tasked with apprehending them. That advantage is even more pronounced in the case of international money laundering, where the predicate crime is committed in one country and the dirty money is laundered in some distant land where law enforcement officials will not even be aware of the existence of the predicate crime. The advantage money launderers possess suggests that anti-moneylaundering legislation should include the following key objectives:

- increasing the visibility of the predicate crime and money-laundering crime;

- removing the anonymity of perpetrators of the predicate crime and enablers of the money laundering crime; and

- increasing the visibility of the relationship between the perpetrators of the predicate crime and enablers of the money-laundering crime.

All three of these objectives could be met by increasing the flow of critical information received by law enforcement agencies from those with knowledge of the predicate crime, its perpetrators and those who help facilitate the laundering of the illicit proceeds. In some cases that information could come from a single person, such as when law enforcement officials catch a perpetrator of the predicate crime (say, a mid-level drug dealer) who strikes a plea deal for a shorter prison sentence in exchange for key information to help trace the illicit proceeds. 
More often, however, individuals will have only pieces of key information. For instance, someone from a distant country might know a corrupt mayor has been extorting money from local merchants and might also know the names of persons close to the mayor (such as family members, trusted friends and business associates) who might be helping him launder that money. But that individual might not know the money was laundered in Canada by the incorporation of a company in Ontario and the purchase of a large house in Toronto.

So, how best to connect people in order to facilitate the flow of critical information? Anti-money-laundering experts have long recognized that beneficial ownership ${ }^{2}$ is the connecting factor between the predicate crime, the flow of its illicit proceeds through the international financial system and the integration of those proceeds back into the legitimate economy through investments in "clean" assets such as real estate. Requiring disclosure of beneficial ownership helps law enforcement agencies connect the clean asset to the perpetrator of the predicate crime.

Accordingly, the first step in an effective anti-money-laundering system is to require disclosure of beneficial ownership. That disclosure should apply to both "clean" assets that are common investments by money launderers (such as real estate and luxury assets) and the legal vehicles used to buy those assets (such as corporations and trusts).

The problem, of course, is that criminals lie. A person who commits a predicate crime and creates a complex scheme to hide the trail of his illicit proceeds is unlikely to disclose that he is the beneficial owner of the clean asset. Instead, the money launderer will use someone he trusts (a relative, close friend or business associate) as a nominee who will falsely declare himself to be the beneficial owner. That is why it is imperative that beneficial ownership information be made publicly accessible. It would allow civil society informants from distant lands (as well as journalists and anti-corruption researchers) to identify a falsely registered beneficial owner as a relative, close friend or business associate of the perpetrator of a predicate crime. As well, a mechanism such as a confidential tip line is needed through which informants can communicate that information to Canadian authorities. It is that two-way flow of information - communication of beneficial ownership information to the world and communication of foreign-based information to Canadian authorities - that could significantly improve Canada's ability to detect, investigate and prosecute money laundering.

That objective is obtainable through the implementation of a publicly accessible registry of beneficial ownership of corporations, business trusts and real estate, with the following key attributes:

- it is internet accessible and usable by anyone for free, with no paywall;

- it requires disclosure of information that maximizes the ability to connect the perpetrator of the predicate crime to the registered nominee - including, for example, full legal name and all other names by which the registrant is commonly known, occupation, citizenships and country of tax residence;

2 In the context of an asset, "beneficial owner" generally refers to the natural person who ultimately owns that asset. In the context of a corporation, trust or other legal entity, "beneficial owner" generally refers to the natural person or persons who own or control that legal entity (FATF 2012). An individual who generates income from the commission of a crime will often hide those illicit proceeds by transferring them into a company or trust and/or investing them in high-value assets such as real estate. Requiring disclosure of beneficial ownership of companies, trusts and real estate would undermine the criminal's ability to hide his identity and his proceeds from crime, and would help law enforcement agencies trace the money back to the criminal. 
- it is in an open-data format that allows searches by various topics, including name, occupation, citizenship, country of birth and residence; and

- it has a tip line that enables informants to provide information confidentially to Canadian authorities. ${ }^{3}$

A key point is that, if such a registry were made private, as recently recommended in the FINA Report, rather than public, Canadian law enforcement agencies would continue to be limited to official sources for their information about money laundering from foreign countries. And that would make little sense when much of the world's money laundering comes from countries where the official sources, such as law enforcement agencies, are controlled by corrupt government officials who are laundering their dirty money in foreign countries, including Canada. ${ }^{4}$

A publicly accessible Canadian registry would overcome that significant limitation by enabling ordinary citizens from other countries to search for listings of corrupt officials or their family members, close friends or business associates as beneficial owners. By adding the eyes and voices of those ordinary citizens, who are often subjected to a life of poverty by corrupt government officials, Canada could revolutionize the ability of law enforcement agencies to detect, investigate and prosecute money-laundering crimes.

\section{The Money-Laundering Rabbit Hole}

When law enforcement agencies apprehend the perpetrators of an underlying predicate crime, it is difficult but far from impossible for them to trace the illicit proceeds from the predicate crime to the "clean" assets that eventually were purchased. Although the money trail often involves multiple corporations and trusts in numerous jurisdictions, law enforcement agencies can offer perpetrators reduced prison sentences in exchange for information facilitating the tracing of illicit proceeds.

The situation is completely different, however, when a law enforcement agency has not even detected a predicate crime from which to start an investigation, and instead is tasked with tracing the money from the "clean" asset back to the predicate crime. Until that connection is proven, there is no crime with which anyone can be charged. Even if the agency knows that persons are involved in a suspicious transaction, it is limited in its ability to persuade them to cooperate. ${ }^{5}$ Without cooperation, following money from the "clean" asset back to the predicate crime is extremely difficult, for two reasons. First, the agency is beginning an investigation not of a crime, but of a suspicion of a crime, which significantly weakens its ability to obtain the cooperation of foreign

3 The anonymity of informants would be guaranteed by protections similar to those provided under the Canadian CrimeStoppers System.

4 See, for example, Global Financial Integrity, "Illicit Financial flows to and from Developing Countries 2006 to 2015," available online at https://www.gfintegrity.org/issues/data-by-country/; and Transparency International's Corruption Perceptions Index 2018, online at https://www.transparency.org/cpi2018.

5 In R. v. Jarvis [2002] SCR 73, the Supreme Court of Canada held that the principle against self-incrimination is "an elemental canon of the Canadian criminal justice system." Under section 7 of the Charter of Rights and Freedoms, persons have the right to silence and can refuse to answer questions or provide documents requested by law enforcement agencies. Charter protections also extend to questions posed or documents requested by other government agencies (such as the Canada Revenue Agency, the Canada Border Services Agency, and the Office of the Superintendent of Financial Institutions) during an investigation where the predominant purpose of the investigation is the determination of penal liability (has a crime been committed?). 
governments and disclosure orders from foreign courts. Second, the investigation often involves tracing money back through multiple companies and trusts in numerous countries, and then proving that the ultimate beneficial owner acquired those funds from the commission of a predicate crime.

Such an endeavour has an extremely low probability of success. As soon as law enforcement officials trace the dirty money through three or four layers of companies and trusts in multiple jurisdictions (which often takes months, sometimes years), the money launderers can simply add three or four more layers of companies and trusts. Further, money launderers often use lawyers as nominee directors, shareholders and trustees, and invoke solicitor-client privilege in response to any court application by law enforcement officials for disclosure of beneficial ownership, corporate share registers and trust documents. Finally, money launderers can send the money trail into a dirty jurisdiction, such as Nevis, where strict privacy laws preclude legitimate court applications for disclosure. Ultimately, law enforcement agencies have little choice but to give up because of their limited time, manpower and money. In other words, because the money-laundering trail is a rabbit hole that can always be dug deeper, it is almost impossible for law enforcement agencies to work backwards from the "clean" asset to the predicate crime.

That significant disadvantage suggests key objectives of anti-money-laundering legislation should include the following:

- creating a new chargeable offence above the money-laundering rabbit hole, such as falsely declaring beneficial ownership of a "clean" asset;

- attaching significant sanctions that include imprisonment ${ }^{6}$ for the most serious offences, which law enforcement officials could use as leverage to obtain information leading to the underlying predicate crime; and

- enacting legislation, such as unexplained wealth orders, that requires persons connected to a suspicious transaction to disclose information helpful to the tracing of illicit funds, such as beneficial ownership and sources of wealth and funding.

To meet those objectives, the following changes to Canada's money-laundering laws are suggested:

- all Reporting Entities ${ }^{7}$ should have to request beneficial ownership information from their customers; ${ }^{8}$

6 Sanctions that include only fines are unlikely to be a significant deterrent to most money launderers because they can simply offer to reimburse nominees for any applicable fine. Prison sentences are completely different. Without the ability to eliminate the hardship of the sanction, money launderers are exposed to the significant risk that law enforcement agencies will convince a nominee to accept a reduced prison sentence in exchange for the evidence needed to trace the illicit proceeds back to the predicate crime and its perpetrators.

7 "Reporting Entities" refers to financial services providers (such as banks, investment banks, credit unions, trust companies and insurance companies) and designated non-financial businesses and professions (DNFBPs) that are required under the Proceeds of Crime (Money Laundering) and Terrorist Financing Act to file reports with the Financial Transactions and Reports Analysis Centre.

8 Currently, only financial services providers are required to collect beneficial-ownership information from their customers. DNFBPs are not so required, even though this has been the international standard, as set out in the recommendations of the FATF (FATF 2012), since 2012. The FINA Report (Canada 2018) recommends extending the requirement to all Reporting Entities, which is to be commended. Unfortunately, the Report does not also recommend that customers who provide false beneficial-ownership information to Reporting Entities be subject to sanctions, including imprisonment for intentionally false declarations. 
- customers who provide beneficial ownership information to Reporting Entities should have to do so by declaration;

- beneficial ownership information filed on a registry also should have to be made by declaration;

- false declarations should be subject to sanctions that include imprisonment; ${ }^{9}$ and

- the use of unexplained wealth orders, ${ }^{10}$ an investigative tool that extends the government's existing civil recovery scheme, should be authorized.

These changes would create a potential offence above the money-laundering rabbit hole, thereby providing law enforcement agencies with a stronger base from which to follow the money. With more than just a suspicious transaction to work with, they could not only negotiate plea deals to obtain needed information to trace illicit funds, but also increase their ability to obtain disclosure orders from foreign courts.

\section{Privacy Rights}

Those who object to a public registry claim it would be an infringement on privacy rights. And they are right. Legislation requiring public disclosure of beneficial ownership would be an infringement on privacy rights granted under section 8 of the Charter of Rights and Freedoms. ${ }^{11}$ But section 1 of the Charter authorizes infringements of rights where it is reasonable and demonstrably justified in a free and democratic society. ${ }^{\mathbf{1 2}}$

9 Offences might also include false or deceptive statements, false or deceptive documents, and conspiracy to engage in prohibited activities. (For precedent purposes, see section 239(1) of the Income Tax Act.) In the 2019 federal budget, the Canadian government proposed adding "recklessness" to the offence of money laundering, which would criminalize the activity of moving money while ignoring the risk that the money is connected to a predicate crime. This proposed legislative change, which is based on Transparency International Canada's suggestion, would also help law enforcement agencies trace the proceeds of crime because it would create an offence above the money-laundering rabbit hole.

10 If a court issues an unexplained wealth order, the respondent should be compelled to reveal the sources of his wealth, including a satisfactory explanation of how he lawfully obtained the property in question. If he failed to do so, the government should be able to apply to the court to seize the property. To prevent overreach by law enforcement agencies, they should have to prove, as a precondition to an application for an unexplained wealth order, that the value of the property is greater than some designated amount (such as $\$ 100,000$ ); there are reasonable grounds for suspecting that the known sources of the respondent's lawfully obtained income are insufficient to enable the respondent to obtain the property; and either (i) the respondent is a Politically Exposed Person or Head of an International Organization from a foreign country or (ii) there are reasonable grounds to suspect the respondent (or a person with whom he or she is connected) is or has been involved with serious crime, whether in Canada or elsewhere.

11 In Hunter v. Southam [1984] 2 SCR 145, the Supreme Court of Canada held that section 8 of the Charter (the right to be secure against unreasonable search and seizure) guarantees a person's right to privacy from state intrusion. Privacy rights are also protected under numerous federal, provincial and territorial statutes, such as the Privacy Act, RSC, 1985, c. P-21; the Freedom of Information and Protection of Privacy Act, R.S.0. 1990, c. F.31; and the Access to Information and Protection of Privacy Act, S.N.W.T. 1994, c.20.

12 Section 1 of the Charter both guarantees all rights and freedoms under the Charter and authorizes limitations on those rights to the extent such limitations are reasonable as can be demonstrably justified in a free and democratic society. 
The Supreme Court of Canada has set out four criteria ${ }^{13}$ to determine whether an infringement of a right is reasonable and demonstrably justifiable. Only two are contentious in the context of a public registry: "leastintrusive alternative" and "proportionality between the effects and measures."

\section{The Least-Intrusive Alternative}

The least-intrusive alternative to a public registry of beneficial ownership is a private registry. Anything less than a registry system - simply doing more of the same - is unlikely to improve Canada's 99.9 percent failure rate in catching money launderers.

A private registry, however, has an inherent flaw: as access is widened to make the registry more effective, the added protection of privacy compared to a public registry becomes illusory. For instance, the FINA Report (Canada 2018) recommends a private registry accessible by more than 31,000 Reporting Entities, which collectively have hundreds of thousands of employees. Even if safeguards were put in place to restrict access to only a few employees per Reporting Entity, it is difficult to believe tens of thousands of individuals would keep registry information a secret. ${ }^{14}$ But even wider access is needed in today's global economy. It is fundamental to the effective combating of money laundering in Canada that journalists, anti-corruption researchers and civil society informants from around the world have access to registry information so they can communicate invaluable information to Canadian authorities. ${ }^{15}$

A more constructive alternative would be a public registry that divided filed information into publicly accessible and strictly confidential compartments. Basic information ${ }^{\mathbf{1 6}}$ needed to connect perpetrators of crimes to their registered nominees would be publicly accessible. Sensitive information, such as passport numbers and full residential addresses, would be protected as strictly confidential and accessible only by the registrar to verify filed information and by law enforcement agencies on a need-to-know basis. That compartmentalization of public

13 The four criteria were set out in R. v. Oaks [1986] 1 SCR 103. The other two criteria are (i) "necessity" (is the objective of combatting money laundering a pressing and substantial concern?), which the Supreme Court answered in the affirmative in Canada (Attorney General) v. Federation of Law Societies of Canada [2015] 1 SCR 401 at para 59; and (ii) "rational connection" (is the objective of combatting money laundering rationally connected to the implementation of a public registry?), which is self-evident.

14 The FINA Report (Canada 2018) recommends additional categories of Reporting Entities. If that recommendation were implemented, the number of persons with access to the registry would likely exceed 100,000.

15 This is particularly true where the predicate crime originates in a country that is not a liberal democracy with a strong rule of law. In such a case, it is often futile for Canadian officials to seek information through formal legal channels because the perpetrators of the predicate crimes are close to power in those foreign countries. A public registry that facilitates the two-way flow of information - beneficial ownership information to the world and foreignbased information back to Canadian authorities through a tip line - would help produce evidence where otherwise there would be none. A private registry, which would surrender that significant advantage, is a less viable alternative because of its narrow ability to facilitate the flow of critical information needed to combat money laundering in Canada effectively.

16 This information would include the legal name and all other names by which the person was commonly known, month and year of birth, citizenships, occupation and country of tax residence. 
and confidential information within a public registry system would enable Canada to combat money laundering better while minimizing intrusions into privacy.

\section{Proportionality between the Effects and Measures}

The proportionality test requires measuring the benefits of a public registry against the effects of a reduction of privacy. Put colloquially, does the gravity of the illness justify the side effects of the medication? And that raises the question: How big is the problem of money laundering in Canada? Because of the invisibility of money laundering, it is not possible to estimate accurately the amount laundered, but that does not mean an effort should not be made to gain some appreciation of its magnitude.

In 1998, the International Monetary Fund (IMF) estimated annual global laundered money at 2 to 5 percent of world gross domestic product (GDP) ${ }^{17}$ (Camdessus 1998, p. 1). As Meunier (2018) notes, "[i]f those percentages were applied to Canada's 2016 [GDP] of approximately $\$ 2$ trillion, it would represent a range of $\$ 40$ billion to $\$ 100$ billion of dirty money laundered. The RCMP's estimates are more modest. In 2011, it estimated that between $\$ 5$ billion and $\$ 15$ billion was laundered." The difference between the IMF-based estimate and the RCMP's estimate is startling; it is as if they were measuring two different things. And they likely were.

The RCMP's estimate makes sense only if it is one of money laundering from predicate crimes committed solely in Canada. ${ }^{18}$ But money laundered in Canada also comes from international sources. And because Canada's anti-money-laundering protections (particularly as they pertain to real estate) are among the weakest of those

17 The "consensus range" of money-laundering transactions as 2-5 percent of global GDP was first announced in 1998 by the IMF, based on 1996 statistics and amounting to between US\$590 billion and US\$1.5 trillion (Moulette 2000). Since that time, other institutions such as the United Nations Office of Drugs and Crime (UNODC) have referred to that percentage consensus range in their discussions, and it has been widely accepted in the international community. In 2011, the UNODC conducted its own study of crime and laundered funds that occurred in 2009 (the study focused on the cocaine trade and extrapolated for other crimes), and stated that its best estimate of criminal proceeds for that year was 3.6 percent of global GDP, of which 2.7 percent was laundered through the international financial system (UNODC 2011, p. 7). Further, in confirming the 2-5 percent of GDP consensus range, the UNODC stated: "If tax and customs-related money laundering activities were included in the calculation, results would move towards and perhaps exceed - the upper end of the [2-5 percent] consensus range" (UNODC 2011, p. 9). Tax crimes are now included in Canada's Criminal Code definition of proceeds of crime, which suggests an appropriate estimate of global money laundering in 2018 would be $\$ 5$ trillion (5 percent of $\$ 100$ trillion) of which $\$ 3.75$ trillion $(2.7 / 3.6 \mathrm{X}$ $\$ 5$ trillion) was laundered through the international financial system. Note: As at November 8, 2018, FINTRAC states criminal proceeds are "estimated at some $\$ 590$ billion to $\$ 1.5$ trillion (US) worldwide each year." Those numbers appear to be 1996 estimates. See http://www.fintrac-canafe.gc.ca/fintrac-canafe/definitions/money-argent-eng.asp. See also http://oecdobserver.org/news/archivestory.php/aid/244/Money_laundering:_staying_ahead_of_the_latest_trends. html.

18 The RCMP has not disclosed how it arrived at its 2011 estimate. Using the IMF consensus range of $2-5$ percent, the estimated range of laundered money in Canada in 2011 would be between $\$ 34.4$ billion and $\$ 86$ billion. Using the UNODC's best estimate of 2.7 percent, that would be $\$ 46.5$ billion. Both estimates would be significantly higher if they included illicit proceeds from tax- and customs-related crimes, which have been part of Canada's Criminal Code definition of "proceeds of crime" since 2010. 


\section{Box 1: Canada’s Anti-Money-Laundering Protections for Real Estate}

Canada allows companies, trusts and nominees to purchase real estate without disclosing beneficial ownership; ${ }^{a}$ realtors are not required to collect beneficial-ownership information, and they have a dismal record of complying with their present minimal anti-money-laundering obligations; beneficial ownership is not available for public scrutiny; and solicitor-client-privilege obligations prohibit lawyers from disclosing beneficial ownership information to regulators or reporting their clients' suspicious transactions. Although Canadian banks have strong anti-money-laundering systems pertaining to their own customers, they do not have beneficial-ownership information for recipients of funds wired into lawyers' trust accounts, and they do not receive, as a matter of course, beneficial-ownership information for senders of international wire transfers they receive. For the latter, they rely on correspondent banks, which Canadian banks vet to ensure they have substantially similar anti-money-laundering systems, but it still means the protections provided by Canadian banks are only as strong as those of their weakest correspondent banks. Further, even the best anti-money-laundering systems in the world have limited ability to prevent illicit money flows from trade-based money laundering, where criminals create legitimate businesses that commingle licit and illicit proceeds, or they transfer value from one country to another by using fraudulent transfer pricing such as undervaluing or overvaluing imported goods and services.

Finally, money launderers can avoid Canada's formal banking system altogether by using informal value-transfer systems (also known as parallel banking, underground banking or alternative remittance systems) that transfer money for the purpose of making an equivalent amount of funds payable to a third party in another geographic location, whether or not in the same form. The transfer often takes place outside conventional banking systems, and brokers often use trade-based value-transfer systems to settle accounts with other brokers (Cassara 2016).

The BC legislature recently introduced Bill 23 - 2019: Land Owner Transparency Act - which, if enacted, will require companies, trusts and partnerships purchasing real estate in $\mathrm{BC}$ to disclose their beneficial ownership on a public registry.

of the western liberal democracies (Meunier 2018; see also Box 1), Canada likely receives a significant amount of that international dirty money. ${ }^{19}$ Therefore, the true estimate is unlikely to be below the range of $\$ 40$ billion

19 There are two key reasons international money launders prefer to send their dirty money to western liberal democracies: better cleaning and protection from confiscation. International money launderers know that dirty money is considered "cleaner" (more easily integrated into the legitimate economy) if it can be made to appear to have originated from a western liberal democracy. Attempts to "clean" dirty money by transferring it to a country with a reputation for corruption or with a restricted currency (such as Russia, China or Saudi Arabia) is of little benefit because money transfers coming out of such countries tend to be closely scrutinized by the international banking community and likely will raise a red flag. In western liberal democracies, when such investments are sold, money launderers consider the proceeds to be "clean" because they are generally transferable throughout the international banking system without raising a red flag. Additionally, the rule of law in western liberal democracies provides protection against arbitrary confiscation of assets. Kleptocrats and criminals from autocratic and developing countries seek such protections because they know that, if they leave their criminally obtained assets at home, they risk arbitrary confiscation from someone better connected to power (Petraeus and Whitehouse 2019).

Together, these two benefits - better cleaning and protection from confiscation - provide strong incentives for international money launderers to send a disproportionately high percentage of their proceeds of crime to western liberal democracies. And western democracies with weak anti-money-laundering protections, like Canada, likely receive a disproportionately high percentage of the dirty money coming to them. In other words, it is doubly likely that a disproportionately high percentage of the world's dirty money is flowing into Canada. This suggests that, to maximize the effectiveness of Canada's anti-money-laundering policies, we need to be mindful of not just how Canadian criminals think and act but, more important, how criminals from all parts of the world think and act. More specifically, we need to adopt an international perspective when analyzing the problem of money laundering in Canada. 
to $\$ 100$ billion, and might exceed it. ${ }^{20}$ This suggests the possibility that, over the last several years, hundreds of billions of dollars in dirty money has been laundered in Canada, probably a good portion in Vancouver and Toronto real estate where millions of dollars of dirty money can be laundered in a single transaction.

But the problem is much larger than the harm caused to Canadians. ${ }^{21}$ International dirty money is a derivative of its underlying crimes. From drug trafficking to human trafficking to political corruption, these crimes inflict incalculable human suffering around the globe, and are particularly damaging to developing nations. The flight of their capital, in the form of dirty money, limits government revenue, impairs economic growth and worsens poverty and inequality (Baker 2005, p. 50). "The cause and effect relationship between dirty money and global inequality is not some vague, abstract notion. It's an overarching reality in today's world” (Baker 2005, p. 209).

In a liberal democracy, loss of privacy, even if limited in scope, is a significant matter. But when weighed against the potentially enormous benefits of a public registry - in particular, the reduction of harm inflicted on Canadians and other global citizens - the requirement to disclose beneficial ownership of corporations, business trusts and real estate would seem to be justified.

\section{Conclusion}

Money launderers enjoy the advantages of anonymity, the invisibility of their crime, and legal obstacles to following their dirty money. By adopting structures that directly and indirectly target these advantages, Canada could combat money laundering more effectively.

Anonymity and invisibility could be reduced by implementing a publicly accessible registry of beneficial ownership of companies, trusts and real estate. Structured properly, a public registry would offer a two-way flow of information - communication of beneficial ownership information to the world and communication of foreign-based information to Canadian authorities - which would bring more bad guys into the light of day. Obstacles to following the money could be reduced by creating a new criminal offence: a false declaration of

20 Using the estimate of $\$ 3.75$ trillion entering the international financial system (see footnote 17) and assuming 70 percent of the $\$ 3.75$ trillion ( $\$ 2.625$ trillion) is laundered in western liberal democracies, Canada's proportionate GDP share (4 percent of the total GDP of western liberal democracies) would be $\$ 105$ billion. But since Canada's antimoney-laundering protections are weaker than those of many other western liberal democracies, it is likely receiving more than its GDP-percentage share of dirty money. For instance, assuming Canada receives 5 percent of that money, its estimated 2018 foreign proceeds of crime would be about $\$ 130$ billion. Admittedly, that estimate is extremely rough, and should not be relied upon as anything more than an order of magnitude of the problem, but it does suggest that Canada has a very large money-laundering problem, predominantly sourced from foreign countries.

21 Money laundering in Canadian real estate artificially inflates house prices and rents and increases the number of vacant houses. International money launderers are likely to leave their houses empty because renting increases their risk of detection. Tenants will want to pay by cheque or bank transfer, both of which bring the international money launderer into the Canadian banking system and its more rigorous anti-money-laundering detection systems. Legitimate property managers are not a viable alternative because they are required to withhold 25 percent nonresident tax, submit that amount to the Canada Revenue Agency and disclose to the agency the identity of the foreign owner, which increases the money launderer's risk of detection. As a result, houses sit empty, hollowing out the economy. There are no occupants to buy groceries, clothing or gas, or go to restaurants, hair salons or the theatre, which reduces sales revenues for local merchants and tax revenues for the government. 
beneficial ownership, whether made on a public registry or submitted by a customer to a Reporting Entity. Not only would such an offence bring more integrity to the beneficial-ownership information being disclosed; it would also provide a solid base from which law enforcement agencies could conduct investigations of suspicious transactions.

Implementation of these two recommendations should fundamentally improve Canada's ability to combat money laundering and reduce the harm it inflicts upon Canadians and other global citizens. Perhaps then Canada will no longer fail to catch money launderers 99.9 percent of the time. 


\section{References}

Baker, Raymond W. 2005. Capitalism's Achilles Heel. Hoboken, NJ: John Wiley \& Sons.

Camdessus, Michael. 1998. "Money Laundering: The Importance of International Countermeasures.” Speech to the Plenary Meeting of the Financial Action Task Force on Money Laundering. Paris. International Monetary Fund. Washington D.C. Available online at https://www.imf.org/en/News/ Articles/2015/09/28/04/53/sp021098.

Canada. 2018. House of Commons Standing Committee on Finance. "Confronting Money Laundering and Terrorist Financing: Moving Canada Forward.” Ottawa. Available online at http://www. ourcommons.ca/DocumentViewer/en/42-1/FINA/report-24/.

Cassara, John A. 2016. Trade-Based Money Laundering. Hoboken, NJ: John Wiley \& Sons.

FATF (Financial Action Task Force). 2012. "International Standards on Combating Money Laundering and the Financing of Terrorism \& Proliferation." Paris: FATF. Available online at http://www.fatfgafi.org/media/fatf/documents/recommendations/pdfs/FATF\%20Recommendations\%202012.pdf.

Meunier, Denis. 2018. Hidden Beneficial Ownership and Control: Canada as a Pawn in the Global Game of Money Laundering. Commentary 519. Toronto: C.D. Howe Institute.

Moulette, Patrick. 2000. "Money Laundering: Staying Ahead of the Latest Trends." OEDC Observer. Available online at http://oecdobserver.org/news/archivestory.php/aid/244/Money_laundering:_ staying_ahead_of_the_latest_trends.html.

Petraeus, David, and Sheldon Whitehouse. 2019. "Putin and other authoritarians' corruption is a weapon - and a weakness." Washington Post, March 8.

UNODC (United Nations Office of Drugs and Crime). 2011. Estimating Illicit Financial Flows Resulting from Drug Trafficking and Other Transnational Organized Crimes. Vienna: UNODC. Available online at https://www.unodc.org/documents/data-and-analysis/Studies/Illicit_financial_flows_2011_web. pdf.

This E-Brief is a publication of the C.D. Howe Institute.

Kevin Comeau is a retired lawyer who has written on policy and legislative proposals to combat money laundering in Canada. He is a member of Transparency International Canada's Working Group on Beneficial Ownership Transparency.

This E-Brief is available at www.cdhowe.org.

Permission is granted to reprint this text if the content is not altered and proper attribution is provided. The views expressed here are those of the author. The C.D. Howe Institute does not take corporate positions on policy matters. 